Biografistyka Pedagogiczna

Rok 6 (2021) nr 1

ISSN 2543-6112; e-ISSN 2543-7399

DOI: 10.36578/BP.2021.06.06

\title{
Alicja Lisiecka*
}

\section{O pedagogicznym znaczeniu piękna w świetle biografii Williama Morrisa (1834-1896)}

\author{
On the Pedagogical Importance of Beauty in View \\ of the Biography of William Morris (1834-1896)
}

\begin{abstract}
The aim of this article is to consider the problem of the pedagogical importance of beauty in view of the biography of William Morris. The author poses a question about the impact of life experiences and socio-economic conditions in 19th-century England on Morris's views on the pedagogical meaning of beauty, i.e. beauty that leads to pro-personal and pro-social change. The author refers to Polish and English biographical studies, articles and sources.
\end{abstract}

Keywords: William Morris (1834-1896), aesthetic beauty, aesthetic education, social pedagogy.

* Alicja Lisiecka (oRCID: 00oo-0oo3-0o8o-6314) - dr, adiunkt na Wydziale Pedagogiki i Psychologii Uniwersytetu Marii Curie-Skłodowskiej w Lublinie, kontakt: a.lisiecka@poczta.umcs.lublin.pl. 
W illiam Morris zapisał się w historii jako ceniony artysta-rzemieślnik, krytyk i malarz, jeden z najbardziej znanych poetów epoki wiktoriańskiej, odnoszący sukcesy przedsiębiorca, protoplasta współczesnych ruchów ekologicznych oraz zaangażowany reformator życia społecznego ${ }^{1}$. Morris należał do nielicznego grona myślicieli, którzy wykorzystując przyrodzoną wszechstronność i liczne talenty, usiłowali objąć myślą pełnię ludzkiej egzystencji. W działalności Morrisa wyraźnie zarysowuje się pragnienie zintegrowania wartości życia miejskiego z życiem wiejskim, przeszłości z teraźniejszością, odpowiedzialności społecznej z moralnością osobistą. William Morris był postacią złożoną, niekiedy nierozumianą; osobowością w pełnym tego słowa znacze$n^{n}{ }^{2}$. Jak pisze jego biografka Fiona MacCarthy, do końca życia zachował duszę dziecka i niewinność idealisty³.

Dla społecznej aktywności Morrisa - przenikającej się na różnych poziomach z jego działalnością artystyczną - kluczowe są dwie kategorie: pracy i piękna. W swoich poglądach na obie te kwestie Morris zbliżał się do przekonań innego wybitnego Anglika - Johna Ruskina; rozszerzał je jednak i modyfikował. Podobnie jak John Ruskin ${ }^{4}$, Morris był przeciwnikiem niepohamowanej industrializacji, wyzysku robotników, degradacji środowiska i jakości życia; ale w przeci-

1 F. MacCarthy, William Morris. A Life for Our Time, Londyn 2010, s. VII.

2 Leon Winiarski tak opisuje Morrisa: „Widziałem go dwukrotnie: raz w Londynie, w roku 1887, i następnie w Paryżu, w 1889 roku. Był to człowiek średniego wzrostu, o potężnej, lwiej głowie, z wysokim masywnym czołem, na które spadały kosmy nieposłusznych, rozczochranych, siwiejących włosów. Brodę miał nieostrzyżoną patriarchy, a oczy niebieskie, pełne idealizmu, dobroci i wiary w siebie. By uwolnić się od niewygody krochmalnych kołnierzy i gorsów, nosił pod surdutem niebieską bluzę robotnika - artysty, skórzanym pasem ściągniętą. Postać jego tchnęła spokojem, siłą, pewnością siebie, uczuciem człowieka, który całą swą energię poświęcił celowi szlachetnemu i jest przekonany o jego pożyteczności i trumfie ostatecznym"; L. Winiarski, William Morris, Warszawa 1900, s. 2.

3 F. MacCarthy, William Morris, s. VII.

4 A. Lisiecka, Recepcja poglądów Johna Ruskina na wychowanie w Polsce przełomu XIX i XX wieku, „Biuletyn Historii Wychowania”, 42 (2020) s. 145-158, DOI: 00oo-ooo3o08o-6314; A. Lisiecka, „Piękno uspołecznione”. Poglądy Johna Ruskina na społeczeństwo i wychowanie, w: Edukacja jutra. Oferta edukacyjna odpowiedzią na problemy wspótczesności, red. A. Kamińska-Małek, P. Oleśniewicz, Warszawa 2020, s. 64-71. 
wieństwie do swojego mistrza ${ }^{5}$, nie ograniczał się jedynie do budowania teorii, lecz oczekiwał przeprowadzenia rzeczywistej zmiany społecznej i do niej dążył.

Morris postulował o uszlachetnienie monotonnej i często wyczerpującej pracy fizycznej przez włączenie weń pierwiastka twórczości i swobody, tak aby stała się ona źródłem satysfakcji i przyjemności, a nie codziennej udręki przytępiającej umysł i zmysły. Za cel postawił sobie zdemokratyzowanie sztuki ${ }^{6}$, którą postrzegał jako dźwignię życia społecznego ${ }^{7}$. U podstaw jego założeń znajdowało się głębokie „umiłowanie piękna i wiara, że piękno ma znaczenie społeczne" rozpowszechnione na drodze reform może przyczyniać się do stworzenia lepszej przyszłości dla wszystkich. Piękno zewnętrzne było w przypadku Morrisa Ruskina także - równie ważne jak wewnętrzne piękno duszy. Pisał: „Niepodobna mi jednak zapomnieć, że w myślach mych nie mogę absolutnie oddzielić sztuki od moralności, polityki i religii”" . Morris pragną̧, aby piękno stało się integralną częścią istnienia każdego człowieka, czyniąc je szczęśliwszym i pełniejszym.

Celem niniejszego artykułu jest przyjrzenie się pedagogicznym aspektom piękna w kontekście biografii Williama Morrisa. Procesem badawczym kieruje pytanie o wpływ doświadczeń życiowych oraz niepowtarzalnego klimatu epoki ${ }^{10}$ na poglądy Morrisa w kwestii pedagogicznego znaczenia piękna. Przez

5 Morris i Ruskin darzyli się uznaniem i sympatią, chociaż nie znali się dobrze i spotkali jedynie kilka razy. Bliższa relacja łączyła Ruskina z wieloletnim przyjacielem Morrisa - Edwardem Burne-Jonesem. Prace Ruskina miały znaczący wpływ na rozwój poglądów Morrisa. W okresie studiów w Oxfordzie Morris przeczytał Kamienie Wenecji (1853) (dokładnie tom trzeci; pierwsze dwa Morris znał już wcześniej), które zrobiły na nim ogromne wrażenie i na długi czas ukształtowały spojrzenie na kwestie sztuki, polityki, stosunków społecznych i architektury (K. Jackson, The Worlds of John Ruskin, London 2018, s. 72). Morris przyznał, że to dzięki Ruskinowi nauczył się dawać wyraz własnemu niezadowoleniu, poprzez tworzenie rzeczy pięknych i niechęć do nowoczesnej cywilizacji (tamże, s. 141).

6 W. Morris, Nadzieje i troski sztuki. Cztery odczyty, Warszawa 1902, s. 102.

7 K. Kosiński, Szermierze sztuki uspołecznionej (Tołstoj, Morris, Ruskin), Warszawa 1928, s. 75-76.

8 Tamże, s. 36.

9 W. Morris, Nadzieje i troski sztuki, s. 61.

10 W. Szulakiewicz, Biografistyka i jej miejsce w historiografii edukacyjnej po II wojnie światowej, „Biuletyn Historii Wychowania”, 19-20 (2004) S. 12-13, DOI: 10.14746/ bhw.2004.19.20.1. 
określenie „pedagogiczny” należy tutaj rozumieć taki rodzaj działalności społeczno-wychowawczej (teoretycznej i praktycznej), który służy szeroko pojmowanej zmianie proosobowej i prospołecznej.

William Morris urodził się 24 marca 1834 roku w Elm House w Walthamstow, w zamożnej rodzinie należącej do klasy średniej. Ojciec Morrisa, również William, był finansistą, współudziałowcem w odnoszącej sukcesy spółce zajmującej się rozliczeniami, z siedzibą w centrum Londynu. Jego matka Emma, z domu Shelton, była typową przedstawicielką swojego stanu ${ }^{11}$; jej aktywność nie wykraczała poza organizowanie życia rodzinnego. Morris miał dwie starsze siostry i sześcioro młodszego rodzeństwa ${ }^{12}$. Dorastał - jak sam napisał - w typowym dla burżuazji komforcie ${ }^{13}$. Wracając myślami do okresu dzieciństwa, doszedł do wniosku, że jego miłość do piękna musiała być wrodzona, gdyż żadne z rodziców nie przejawiało estetycznych potrzeb czy zainteresowań wykraczających poza wspomniany burżuazyjny komfort ${ }^{14}$. Morris surowo oceniał wczesnowiktoriańskie ${ }^{15}$ wartości, którym hołdowano w jego rodzinie. Nie rozumiał dojmującej potrzeby ciągłego bogacenia się ${ }^{16}$, braku krytycz-

11 A. Gromkowska-Melosik, Ciało, moda i tożsamość kobiety epoki wiktoriańskiej-dyskursy piękna i przemocy, „Kultura - Społeczeństwo - Edukacja”, 2 (2012) s. 17-30, DOI: 10.14746/kse.2012.2.02.

12 F. MacCarthy, William Morris, s. 1-2.

13 Tamże, s. 1.

14 Tamże.

15 W epoce wiktoriańskiej obowiązywało wiele konwenansów i nakazów społecznych regulujących kwestię życia prywatnego, a także ścisłe podziały ról (np. kobiet i mężczyzn) oparte na specyficznym pojmowaniu moralności (I. Dobosiewicz, Od Anioła domowego ogniska do Nowej Kobiety. Kwestia kobieca w wiktoriańskiej Anglii, w: Między tradycją a nowoczesnością: tożsamość kobiety $w$ przestrzeni domu, $w$ historii, kulturze i na drogach emancypacji, red. W. Laszczak, D. Ambroziak, B. Pudełko, K. Wysoczańska-Pająk, Opole 2014, s. 407-114).

16 Na początku XIX wieku narody europejskie uległy zasadniczym przemianom w wymiarze politycznym, prawnym i ekonomicznym (idea wolności i równości obywateli) oraz społeczno-kulturowym (pozycja społeczna zaczęła zależeć od umiejętności pomnażania kapitału, a nie wyłącznie urodzenia). Tendencje społeczne i gospodarcze z pierwszej 
nego oglądu rzeczywistości i szerokich horyzontów ${ }^{17}$. Za godną szacunku uważał jedynie pracowitość, której sam był najlepszym przykładem ${ }^{18}$. Mimo wielu zastrzeżeń, formułowanych już z perspektywy dojrzałego mężczyzny, Morris miał świadomość, że warunki życia rodziny, stanowiące bezpośrednie świadectwo finansowego powodzenia ojca, były dla niego samego rodzajem daru, uśmiechem od losu umożliwiającym mu swobodny intelektualny rozwój ${ }^{19}$.

Morris opisywał swoje dzieciństwo jako idylliczne. Był „szczęśliwym dzieckiem na słonecznych wakacjach". Dom rodzinny postrzegał jako spokojny, stabilny i hojny. Dorastał w otoczeniu pięknej przyrody. Elm House posiadał ogród - miejsce dla Morrisa niemalże magiczne - rezydencję Woodford Hall ${ }^{20}$ otaczał pięćdziesięcioakrowy park, dalej zaś rozciągały się tereny rolnicze i łąki, gdzie wypasano zwierzęta, rósł las i płynęła rzeka, w której William łowił ryby.

połowy wieku swój punkt kulminacyjny osiągnęły w latach siedemdziesiątych i osiemdziesiątych, czyli okresie, w którym nastąpiła rewolucja przemysłowo-cywilizacyjna (1870-1914). „W latach 70. i 80. XIX w. zapoczątkowane zostało przechodzenie od klasycznego kapitalizmu wolnorynkowego (liberalnego) do kapitalizmu monopolistycznego (imperialistycznego), co spowodowały kolejne kryzysy ekonomiczne, a w konsekwencji doprowadziło do powstawania społeczeństwa masowego. Istotne znaczenie miał pierwszy na światową skalę kryzys gospodarczy w 1873r., który ogarnął niemal całą gospodarkę światową oraz druga rewolucja przemysłowa, która doprowadziła nie tylko do przemian dotychczasowego życia ludzkości, ale przede wszystkim - postaw ludzkich, a w konsekwencji do powstania nowego modelu społeczeństwa" (M. Żejmo, Istota przemian industrialnych $w$ XIX wieku, „Studia Gdańskie. Wizje i rzeczywistość", 12 (2015) s. 170). Z rewolucją przemysłową wiąże się przyspieszony rozwój w zakresie wynalazczości, nauk ścisłych, produkcji maszynowej (taśmowej) zwiększającej wydajność pracy oraz przyrost ludności miast (co z kolei implikowało pojawienie się nowych problemów socjalnych, zdrowotnych, oświatowych). W zaistniałych warunkach rozwijały się intensywnie ruchy robotnicze (tamże, s. 173-174); powstawały związki zawodowe walczące o prawa pracownika, przeciwne wyzyskowi ludzi i natury - degradacji środowiska przez procesy industrializacji.

17 F. MacCarthy, William Morris, s. 3.

18 Morris był postrzegany jako człowiek wielu talentów, nieprzeciętnie zaangażowany i pracowity. Kiedy umierał, jeden z jego lekarzy za przyczynę złego stanu chorego wskazał: „po prostu bycie Williamem Morrisem i wykonanie pracy przerastającej możliwości dziesięciu mężczyzn" (tamże, s. vII).

19 Tamże, s. 7.

20 Morrisowie przeprowadzili się do Woodford Hall -imponującej georgiańskiej rezydencji, gdy William miał sześć lat, po znacznym wzbogaceniu się Williama Morrisa Seniora. 
Chłopiec najpierw bawił się z siostrami wśród kwiatów w ogrodzie, później chadzał na piesze wycieczki; często także podróżował z ojcem, podziwiając angielskie krajobrazy. Jako dziecko szczególnie wrażliwe na rzeczy i przestrzenie, chłonął piękno natury i sielską atmosferę wsi ${ }^{21}$.

Morris był zdolnym chłopcem. Nauczył się czytać w wieku czterech lat i od tego momentu książki zajmowały w jego sercu miejsce szczególne. Jako siedmiolatek zaczytywał się w powieściach Waltera Scotta, które ukształtowały jego wyobraźnię i wrażliwośćc ${ }^{2}$. Był też dzieckiem, a później młodzieńcem, o trudnym charakterze. Okresy skupienia i spokoju przeplatały się z epizodami nadmiernego pobudzenia ${ }^{23}$. William, podobnie jak ojciec, miał skłonność do melancholii; czuł się „odmieńcem”, banitą, często towarzyszyło mu uczucie wyobcowania ${ }^{24}$. W szkole w Marlborough, do której wyjechał w wieku czternastu lat, niedługo po niespodziewanej śmierci ojca, odbierany był jako ponury i nieobliczalny ${ }^{25}$.Z perspektywy Williama sytuacja wyglądała już nieco inaczej; Marlborough w jego opinii było miejscem prymitywnym, w którym nie nauczył się wiele, gdyż prawie niczego tam nie uczono. Szczęśliwie dla niego szkoła leżała w pięknej okolicy, bogatej w zabytki, których historię zaczął intensywnie studiować. To właśnie w szkolnej bibliotece rozpoczęła się wielka miłość Williama do historii, rozwijana w kolejnych latach podczas nauki na uniwersytecie ${ }^{26}$.

Doświadczenia płynące z kontaktów z naturą w jej pierwotnym stanie znalazły odzwierciedlenie w późniejszych poglądach Morrisa. W drugiej połowie lat 70., w okresie intensywnej działalności społecznej, podczas swoich odczytów apelował o zaprzestanie bezrefleksyjnej wycinki drzew w miastach, zaniechanie nieprzemyślanej renowacji cennych zabytków architektury, a także

21 Tamże, s. 7-9.

22 Tamże, s. 5-6.

23 Epizody nadmiernego pobudzenia i wybuchy złości towarzyszyły Morrisowi przez całe życie. Fiona MacCarthy twierdzi, że miały one związek z formą epilepsji, na którą cierpiał Morris. Najprawdopodobniej odziedziczył chorobę po matce - Emma zmagała się z napadami drgawek - i przekazał córce Jenny (Tamże, s. XIII).

24 Tamże, s. 13, 23.

25 Tamże, s. 29-30.

26 W. Morris, Fragment listu Williama Morrisa do Andreasa Scheu z 5 września 1883 roku, w: E. Goldzamt, William Morris a geneza społeczna architektury nowoczesnej, Warszawa 1967, s. 317. 
wyburzania starych budowli ${ }^{27}$, aby w ich miejsce stawiać domy czynszowe lub kolejne fabryki zanieczyszczające wodę w rzekach, zasnuwające niebo dymem, zabijające naturalne piękno przyrody ${ }^{28}$. Morris tak głęboko łączył idee piękna sztuki i piękna natury, że był skłonny stwierdzić: „Proszę pamiętać, że ktokolwiek, zwłaszcza w wielkim mieście lub na przedmieściu, nierozważnie i lekkomyślnie pozwolili ściąć drzewo, absolutnie nie ma prawa uważać się za miłośnika sztuki”29. Morris uświadamiał sobie współczesnych, że wzmagająca się degradacja środowiska nie jest wcale nieuniknioną konsekwencją postępu, ale ekonomicznej drapieżności i braku elementarnej kultury estetycznej. Wskazywał również, że zmiana w zakresie grabieżczej polityki jest możliwa i konieczna; „Jednakowoż ludzie nie użyją pieniędzy ni czasu do przeprowadzenia podobnych reform, ponieważ wcale nie odczuwają nędzy życia, poniżywszy się do roli urągającej godności ludzkiej"30.

W 1853 r. Morris rozpoczął studia w Oxfordzkim Exeter College. Początkowo przygotowywał się do zawodu duchownego, lecz szybko porzucił pierwotne plany na rzecz intensywnego studiowania historii; zwłaszcza historii średniowiecznej. W tamtym okresie William znajdował się pod silnym wpływem różnych inicjatyw światopoglądowych i artystycznych. Rozpoczął od zaangażowania w ruch High Church, tzw. szkołę Puseya, które szybko ustąpiło fascynacji pismami Ruskina i dziełami Charlesa Kingsleya. W krótkim czasie nowe zainteresowania rozszerzyły się o pasję do poezji ${ }^{31}$ i sztuki. William wstąpił także na praktykę do angielskiego architekta Georgea Edmunda Streeta. Kiedy bliski przyjaciel Edward Burne-Jones zapoznał go z wybitnym malarzem, przedstawicielem szkoły prerafaelitów Dante Gabrielem Rossettim, Morris zapragnął oddać się malarstwu i przez pewien czas zgłębiał tę sztukę ${ }^{32}$.

27 W 1877 r. Morris założył organizację charytatywną „The Society for the Protection of Ancient Buildings".

28 W. Morris, Nadzieje i troski sztuki, s. 31.

29 Tamże, s. 94.

30 Tamże, s. 80 .

31 Wraz z uniwersyteckimi przyjaciółmi Morris założył nawet miesięcznik „The Oxford and Cambridge Magazine", w którym młodzi ludzie dawali wyraz swoim fascynacjom.

32 W. Morris, Fragment listu Williama Morrisa do Andreasa Scheu, s. 318. 
Idea odrodzenia malarstwa zaproponowana przez prerafaelitów, jak i samo malarstwo sztalugowe narzucały Morrisowi ograniczenia, których nie potrafił zaakceptować. Aby dać wyraz swojemu niezadowoleniu stanem sztuki i obowiązującymi realiami, musiał wyjść poza wąskie ramy obrazu. Okazji do tego rodzaju przekroczenia dostarczyła Morrisowi budowa Red House, własnego domu, wzniesionego w 1859 roku, niedługo po zawarciu małżeństwa z Jane Burden $^{33}$. Projekt Red House inspirowany pomysłami Williama wykonał jego przyjaciel - architekt Philip Webb. Dom, utrzymany w duchu odradzającej się ówcześnie w Anglii architektury gotyckiej, stanowił przykład nowego wzorca przestrzenno-dekoracyjnego mieszkania ${ }^{34}$. Prosty i surowy, nawiązujący do konwencji ceglanego muru i średniowiecznej bryły, był zaprzeczeniem eklektycznej zabudowy mieszczańskiej ${ }^{35}$. Red House korespondował z tradycyjną architekturą angielską, zarówno użytkową ${ }^{36}$, jak i sakralną, którą Morris cenił wysoko, $i$ jak już zostało powiedziane, usiłował chronić przed zniszczeniem, rozbiórkami i nieumiejętną renowacją ${ }^{37}$.

33 Jane Burden była muzą Rossettiego. Morrisowi i Burden urodziły się dwie córki Jane i Mary.

34 Opis „modelowego” wnętrza mieszkania wg Morrisa znaleźć można w: W. Morris, Nadzieje i troski sztuki..., s. 99.

35 E. Goldzamt, William Morris a geneza społeczna architektury nowoczesnej, Warszawa 1967, s. 40-43.

$36 \mathrm{~W}$ okresie intensywnej działalności społecznej, przypadającej na późne lata 70. i 80. Morris głosił: „musimy zacząć myśleć o domach, w których przebywamy. Bo muszę wam powiedzieć, że jeśli nie macie zamiaru dążyć do osiągnięcia architektury dobrej i rozsądnej, wszystkie wasze troski i starania o sztukę pozostaną bezowocne. Mówiłem o sztukach ludowych; wszystkie jednak można objąć jednym słowem: architektura; wszystkie są poszczególnymi częściami owej wielkiej całości i punktem wyjścia dla wszystkich jest budowanie domów. [...] Architektura zawiodłaby nas do wszystkich sztuk, jak bywało dawniej; skoro ją jednak lekceważymy, nie troszcząc się o to, jak mieszkamy, naturalnym jest, że inne sztuki mają z tego powodu stanowisko utrudnione. A jestem przekonany, że największy nawet optymista nie zaprzeczy, iż obecne nasze mieszkania są istną hańbą, a ponieważ po największej części zamieszkujemy domy, które dla nas już zostały zbudowane, przeto należy sobie powiedzieć, że nic nam nie pozostaje do czynienia, jak tylko czekać, aż się zawalą" (W. Morris, Nadzieje i troski sztuki, s. 94-95).

37 Tamże, s. 53. 
O ile John Ruskin w swoich pismach zwracał uwagę na wymiar estetyczny i społeczny architektury i jedynie marzył o pięknie obecnym w życiu każdego człowieka, to William Morris wykonał krok od teorii do praktyki ${ }^{38}$. Podczas prac nad Red House Morris i Webb doszli do przekonania, że w Anglii „wszystkie pomniejsze sztuki są w stanie całkowitej degradacji" i zdecydowali się odmienić ten $\operatorname{stan}^{39}$, zastępując „fabryczną tandetę" wyrobami rzemieślniczymi. W 1861 roku wraz z Webbem, Rossettim, Fordem Madoxem Brownem, Burne-Jonesem, Charlesem Faulknerem i Peterem Paulem Marshallem Morris założył firmę Morris, Marshall, Faulkner \& Co. Fine Art Workmen in Painting, Carving, Furniture and the Metals ${ }^{40}$ produkującą sztukę dekoracją i użytkową z wykorzystaniem tradycyjnych technik, wzornictwa i materiałów ${ }^{41}$. Celem spółki, wykonującej i projektującej, m.in. meble, tkaniny, tapety, dywany i witraże ${ }^{42}$, było przywrócenie rzemiosłu charakteru artystycznego, a rzemieślnikowi rangi artysty ${ }^{43}$, a także uczynienie sztuki „popularną" ${ }^{44}$, tj. obecną w codziennym życiu ludzi ${ }^{45}$.

38 N. Pevsner, Historia architektury europejskiej, Warszawa 1976, s. 393.

39 W. Morris, Fragment listu Williama Morrisa do Andreasa Scheu..., s. 318.

40 W 1875 r. Morris został jedynym właścicielem, a firma zmieniła nazwę na Morris \& Co.

41 Firma "Morris, Marshall, Faulkner \& Co" dała początek międzynarodowemu ruchowi Arts and Crafts.

42 Zaprojektowane przez Morrisa i pozostałych artystów wzory przetrwały próbę czasu i można je obecnie zakupić.

43 P. Juszkiewicz, Czy sztuka narodowa może być nowoczesna? Uwagi do genezy polskiego modernizmu, „Rocznik Historii Sztuki”, 43 (2018) s. 18, DOI: 10.24425/rhs.2018.124933.

44 Por. I. Matuszewski, Estetyka jako czynnik wychowawczo-społeczny, w: Pisma, red. J. Muszkowski, t. 1, Warszawa 1925, s. 63.

45 Tak Morris mówił o sztuce stosowanej: „Sztuka ta uczyni nasze ulice zarówno pięknymi jak lasy. Widok ich będzie działał tak samo podniośle, jak widok gór; sztuka ta dostarczy umysłowi rozkoszy i wypoczynku, zamiast przygnęebienia, które nas opanowuje obecnie za przybyciem ze wsi do miasta; każdy będzie miał dom piękny, skonstruowany, jak być powinno a widok ten nastroi go radośnie i wzmocni do dalszej pracy; wszystkie wytwory ludzkie, które nas otaczają i z którymi mamy wciąż do czynienia, będą pozostawać w harmonijnym stosunku z naturą - połączenie piękności i rozsądku; mimo to będą wszystkie pełne prostoty, lecz bez przymieszki dzieciństwa, będą działać podniecająco, nie denerwując. Jak bowiem naszym budowlom publicznym nie brak będzie żadnej piękności ni wspaniałości, na jakie mogą się złożyć ludzki umysł i ręka, tak w prywatnych naszych mieszkaniach, nie znajdzie się nic takiego, co by wskazywało na rozrzutność, arogancję lub samochwal- 
Początkowo nikomu nieznana firma szybko zyskała rozgłos i klientów wywodzących się z bogacącej się klasy średniej ${ }^{46}$. Wyroby rzemieślnicze projektowane i wytwarzane z myślą o całym społeczeństwie trafiały więc do rąk wybranych ${ }^{47}$. Przewrotnie, niepowodzenie ideowe zaowocowało sukcesem finansowym, co Morris odczuwał jako osobistą porażkę ${ }^{48}$.

Zainteresowanie tradycyjnym rzemiosłem wynikało w przypadku Morrisa $\mathrm{z}$ fascynacji historią i średniowieczem oraz niechęci do produkcji maszynowej.

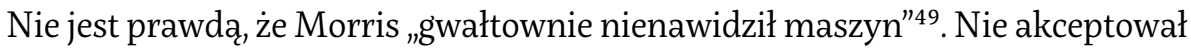
po prostu specyfiki mechanizacji i wynikającego z niej podziału pracy. Deklarował: „Sam wierzę bezwarunkowo w wydajność maszyn. Wierzę, że maszyny zdołałyby wytworzyć wszystko - z wyjątkiem dzieł sztuki"50.

Morris rozpatrywał sztukę i estetykę życia codziennego w szerokim społeczno-moralnym kontekście ${ }^{51}$. Rozumiał, że wychowanie estetyczne nie może ograniczać się do form instytucjonalnych, że musi obejmować najbliższe otoczenie każdego człowieka, które ma decydujący wpływ na kształtowanie wrażliwości i poczucia smaku ${ }^{52}$. Twierdził ponadto: „wykształcenie jest pierwszym lekarstwem przeciw barbarzyństwu, wywołanemu cywilizacją i wolną konkurencją" ${ }^{33}$. Ideały, które Morris wyznawał - jak sam pisał - „zmusiły” go do poszukiwania praktycznych sposobów wdrażania ich w życie ${ }^{54}$. Chociaż

stwo - a każdy otrzyma swą cząstkę najlepszą" (W. Morris, Nadzieje i troski sztuki, s. 34). Prostota nie oznaczała w przypadku produktów Morrisa minimalizmu i ascetyzmu, a raczej wysmakowany gust; bogactwo, np. ornamentu nie oznaczało zbytku, o ile szło w parze z pięknem (por. tamże, s. 100).

46 E. Goldzamt, William Morris a geneza społeczna, s. 45.

47 Koszty rzemieślniczej produkcji okazały się wysokie, co wpływało na finalną cenę towarów.

48 E. Goldzamt, William Morris a geneza społeczna, s. 48.

49 N. Pevsner, Historia architektury europejskiej, s. 394.

50 W. Morris, Sztuka a piękność ziemi, w: W. Morris, R. de la Sizeranne, J. Ree, Podstawy kultury estetycznej, Lwów-Warszawa 1906, s. 21-22.

51 A. Głutkowska-Polniak, Kulturowy wymiar designu - między estetyzacją a odpowiedzialnością, „Załącznik Kulturoznawczy”, 6 (2019) s. 82.

52 J. Mortkowiczowa, O wychowaniu estetycznem, Warszawa 1903, s. 56.

53 W. Morris, Sztuka a piękność ziemi, s. 27.

54 W. Morris, Jak stałem się socjalista, w: E. Goldzamt, William Morris a geneza społeczna architektury nowoczesnej, Warszawa 1967, s. 322. 
niechętny polityce, zaangażował się działalność społeczną i agitacyjną. Został zwolennikiem „praktycznego socjalizmu” ${ }^{55}$. Przyłączał się do różnych ruchów funkcjonujących w ramach rozwijającego się ówcześnie nurtu socjalistycznego. W 1883 r. czterdziestoośmioletni wówczas Morris, człowiek cieszący się uznaniem jako przedsiębiorca, poeta i artysta, wstąpił do Federacji Socjaldemokratycznej, którą opuścił rok później na rzecz Ligii Socjalistycznej. Od 1890 r. przewodniczył wyłącznie Hammersmith Socialist Society. Wydawał także pismo Commonweal $^{56}$. Morrisowi zależało jedynie na poprawie jakości życia najbiedniejszych, dlatego związał się z ruchem socjalistycznym - związał się, należy dodać, nie tyle ideowo, co w praktyce ${ }^{57}$. Od 1878 r. rozwijał pogląd, który on sam nazywał „socjalizmem widzianym oczyma artysty"58. W 1894 r. pisał: „sta-

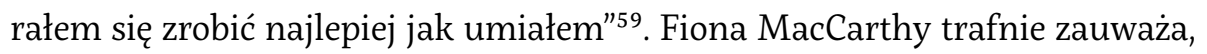
że nie należy utożsamiać socjalistycznych poglądów Morrisa z komunizmem, który ukształtował się w Rosji na początku XX w. Morris „przejrzałby tę politykę od razu" - dodaje biografka ${ }^{60}$.

W Jak stałem się socjalistą Morris pisał:

Może niektórzy nasi przyjaciele zapytają: i cóż nam do tych spraw historii i sztuki? My chcemy przez Socjaldemokrację wywalczyć przyzwoite życie, chcemy jakoś żyć i to od razu. Ktokolwiek głosi pogląd, że sprawy sztuki i kultury muszą stać przed sprawami noża i widelca (a są tacy, którzy tak mówią), nie rozumie chyba, co znaczy sztuka ani tego, że jej korzenie muszą tkwić w glebie życia kwitnącego i wolnego od trosk. Jednak trzeba pamiętać, że cywilizacja doprowadziła robotnika do tak nędznej i żałosnej egzystencji, że on prawie już nie wie, jak sformułować żądanie życia o wiele

55 W. Morris, Jak stałem się socjalistą, s. 323.

56 E. Goldzamt, William Morris a geneza społeczna, s. 54-55.

57 O umiarkowanych poglądach Morrisa świadczy m.in. fakt, że sam był świetnie prosperującym przedsiębiorcą; chociaż we własnej fabryce wprowadził pewne pożądane przez siebie zmiany, to wciąż funkcjonował w rzeczywistości wolnego rynku. Dodatkowo do końca życia zachował uznanie dla Ruskina, który przecież był zdeklarowanym torysem. Warto także podkreślić ogromną niechęć Morrisa do nacjonalizmu i szowinizmu (W. Morris, Fragment listu Williama Morrisa do Andreasa Scheu..., s. 320).

58 W. Morris, Fragment listu Williama Morrisa do Andreasa Scheu, s. 320.

59 W. Morris, Jak stałem się socjalistą, s. 325.

60 F. MacCarthy, William Morris, s. XIX. 
lepszego niż to, które teraz znosi z konieczności. Właśnie zadaniem sztuki jest ukazać mu prawdziwy ideał życia pełnego i rozumnego, życia, w którym kultywowanie i tworzenie piękna, czyli doznawanie prawdziwej radości człowiek będzie odczuwał jako potrzebę niezbędną tak, jak powszedni chleb. I żadnego człowieka ani zespołu ludzi nie będzie można tego pozbawić inaczej niż przez wyraźny opór, któremu trzeba też przeciwstawić się ze wszystkich sił ${ }^{61}$.

Sztuka miała być „osłodą pracy”"62 i źródłem nadziei, a przyzwoity dom położony w pięknej okolicy dostępny dla każdej „pracowitej rodziny” - warunkiem dla istnienia prawdziwej sztuki ${ }^{63}$. Artystyczno-społeczny szczyt swojej wizji Morris osiągnął w Wieściach $z$ Nikąd (Czyli epoce spoczynku) z $1890 \mathrm{r}$. W powieści ${ }^{64}$ Morris snuje romantyczną utopię o krainie, gdzie praca jest pracą rąk, a ludzie oddają się jej z przyjemnością i poświęceniem niczym artyści swojemu dziełu. Społeczeństwo oparte na wymianie dóbr, nieskażona przyroda, spokojna, bezpieczna, wartościowa i przesycona pięknem egzystencja każdego człowieka $^{65}$ - tak Morris widział świat idealny.

William Morris był - jak sam stwierdził - człowiekiem obdarzonym „głłęboką miłością do ziemi i życia na niej oraz namiętnością do dziejów przeszłości rodzaju

61 W. Morris, Jak stałem się socjalista, s. 325-326.

62 W. Morris, Jak stałem się socjalistą, s. 324.

63 W. Morris, Sztuka a piękność ziemi, s. 29.

64 Kilka słów o zmarginalizowanej tutaj aktywności pisarskiej Morrisa: od 1858 r. ukazywały się tomy jego wierszy, przekłady poematów z języka islandzkiego (Morris kilkukrotnie odwiedzał Islandię) i autorskie dzieła inspirowane kulturą Północy, m.in.: The Defence of Guinevere, and other Poems (1858), The Life and Death of Jason (1867), The Earthly Paradise (1868-1870), Love is Enough, or The Freeing of Pharamond (1872), The Story of Sigurd the Volsung and the Fall of the Nibelungs (1876), Hopes and Fears For Art (1882), A Dream of John Ball (1886), The House of the Wolfings (1888), The Roots of the Mountains (1889), News from Nowhere (or An Epoch of Rest) (1890), The Story of the Glittering Plain (1890), The Well at the World's End (1892), The Wood Beyond the World (1895), The Water of the Wondrous Isles (1896), The Sundering Flood (1898).

65 P. Juszkiewicz, Czy sztuka narodowa może być nowoczesna?, s. 18. 
ludzkiego" ${ }^{66}$. Jednostką wrażliwą na piękno sztuki, natury i krzywdę ludzką. Z okresu dzieciństwa wyniósł idylliczną wizję życia, którą zachował w sercu i twórczości do końca swoich dni. Szczególnie bliska relacja łączyła go ze starszymi siostrami i córkami, które w pełni podzielały jego życiowe cele ${ }^{67}$. MacCarthy zauważa, że Morris był jednym z niewielu wybitnych ludzi epoki wiktoriańskiej, którzy dostrzegali deprecjonowanie i niewykorzystany potencjał kobiet, co czyniło go również protoplastą feminizmu ${ }^{68}$. Morrisa cechowało ogromne zaangażowanie, czy to w sprawy produkcji (sam projektował większość wzorów; opanował wiele technik rękodzielniczych, takich jak tkactwo, farbiarstwo itp.), czy to w działalność artystyczną i społeczną. Mimo płomiennej natury zachowywał jednak chłodny ogląd sytuacji i racjonalne spojrzenie na rzeczywistość.

William Morris stworzył podwaliny pod nowe rozumienie sztuki, w którym wartości estetyczne łączą się z etycznymi, a troska o nie staje się obowiązkiem społecznym ${ }^{69}$. Jak dowodzi Nikolaus Pevsner w Historii architektury europejskiej: poprzez odrodzenie wiary w służebną rolę sztuki, poprzez zwrócenie uwagi na potrzebę projektowania pięknych budynków i rzeczy na codzienny użytek, poprzez głoszenie konieczności demokratyzacji sztuki „i przez usilne powtarzanie zasady, że tylko taka sztuka ma znaczenie, w której wszyscy mogą uczestniczyć - tworzył Morris podstawy modernizmu"70. Na zakończenie warto przytoczyć fragment wystąpienia Morrisa opublikowanego w zbiorze Podstawy kultury estetycznej:

Wiecie panowie, gdy siedzę przy pracy w swoim domku w Hammersmith, niedaleko rzeki, wówczas często obijają mi się o uszy te ordynarne rozmowy przechodniów, o czym dawniej i dziś niejednokrotnie tyle pisano w gazetach. Gdy słyszę ów krzyk i wrzask i wszystkie upokorzenia zadawane wspaniałemu językowi Szekspirów i Miltonów; gdy widzę nieokrzesanie i ordynarność bijącą z twarzy i postaci przechodniów, wówczas czuję jak też i we mnie zaczynają się budzić takie same uczucia. Wściekły gniew mnie ogarnia, gdy myślę o tem, że tylko swemu pochodzeniu i bogactwu

66 W. Morris, Jak stałem się socjalista, s. 325.

67 W. Morris, Fragment listu Williama Morrisa do Andreasa Scheu, s. 321.

68 F. MacCarthy, William Morris, s. XIV.

69 A. Głutkowska-Polniak, Kulturowy wymiar designu, s. 81.

70 N. Pevsner, Historia architektury europejskiej, s. 395. 
zawdzięczam to, że znajduję się z tej strony okna, w otoczeniu pięknych książek i miłych dzieł sztuki, a nie z tamtej strony, na pustej ulicy, w szynkach pełnych wyziewu wódki i w mieszkaniach nędznych i ponurych. Jakież słowa zdołają wyrazić, co to wszystko znaczy? Proszę mi wierzyć, że nie jest to bynajmniej zwrotem retorycznym, gdy powiem, że wówczas zważywszy to wszystko, tylko jedno wielkie budzi się we mnie życzenie. A mianowicie, aby nasz możny kraj uwolnił się od wszystkich zawikłań polityki zagranicznej i kolonialnej i użył potężnych sił swego narodu, by dzieciom tych biedaków umożliwić radość i nadzieję. Czyżby to było rzeczywiście niemożliwością? Czy nie można by się spodziewać urzeczywistnienia tych pragnień? Jeżeliby tak być miało, to muszę powiedzieć, że cała nasza cywilizacja jest kłamstwem i blichtrem; że ona wcale nie istnieje i że nie ma też nadziei, aby kiedykolwiek nastała ${ }^{71}$.

Streszczenie: Celem artykułu jest rozpatrzenie problemu pedagogicznej wartości piękna w kontekście biografii Williama Morrisa. Autorka stawia pytanie o wpływ doświadczeń życiowych oraz warunków społeczno-ekonomicznych XIX-wiecznej Anglii na poglądy Morrisa w zakresie pedagogicznego znaczenia piękna, tj. takiego, które służy zmianie proosobowej i prospołecznej. Autorka odwołuje się do opracowań biograficznych, artykułów i źródeł polsko i angielskojęzycznych.

Słowa kluczowe: William Morris (1834-1896), piękno estetyczne, edukacja estetyczna, pedagogika społeczna.

\section{Bibliografia}

Dobosiewicz I., Od Anioła domowego ogniska do Nowej Kobiety. Kwestia kobieca w wiktoriańskiej Anglii, w: Między tradycją a nowoczesnością: tożsamość kobiety $w$ przestrzeni domu, $w$ historii, kulturze i na drogach emancypacji, red. W. Laszczak, D. Ambroziak, B. Pudełko, K. Wysoczańska-Pająk, Opole 2014, s. 407-114.

Głutkowska-Polniak A., Kulturowy wymiar designu - między estetyzacją a odpowiedzialnością, „Załącznik Kulturoznawczy”, 6 (2019) s. 77-90.

Gromkowska-Melosik A., Ciało, moda i tożsamość kobiety epoki wiktoriańskiej - dyskursy piękna i przemocy, „Kultura - Społeczeństwo - Edukacja” 2 (2012) s. 17-30, DOI: 10.14746/kse.2012.2.02..

71 W. Morris, Sztuka a piękność ziemi, s. 30-31. 
Jackson K., The worlds of John Ruskin, London 2018.

Juszkiewicz P., Czy sztuka narodowa może być nowoczesna? Uwagi do genezy polskiego modernizmu, „Rocznik Historii Sztuki”, 43 (2018) S. 11-27, DOI: 10.24425/rhs.2018.124933.

Kosiński K., Szermierze sztuki uspołecznionej (Tołstoj, Morris, Ruskin), Warszawa 1928.

Lisiecka A., „Piękno uspołecznione”. Poglądy Johna Ruskina na społeczeństwo i wychowanie, w: Edukacja jutra. Oferta edukacyjna odpowiedzią na problemy wspótczesności, red. A. Kamińska-Małek, P. Oleśniewicz, Warszawa 2020, s. 64-71.

Lisiecka A., Recepcja poglądów Johna Ruskina na wychowanie w Polsce przełomu XIX i XX wieku, „Biuletyn Historii Wychowania”, 42 (2020) s. 145-158, DoI: 00oo-0oo3oo80-6314.

MacCarthy F., William Morris. A Life for Our Time, London 2010.

Matuszewski I., Estetyka jako czynnik wychowawczo-społeczny, w: Pisma, red. J. Muszkowski, t. 1, Warszawa 1925, s. 57-64.

Morris W., Fragment listu Williama Morrisa do Andreasa Scheu $z 5$ września 1883 roku, w: Goldzamt E., William Morris a geneza społeczna architektury nowoczesnej, Warszawa 1967, s. 317-321.

Morris W., Jak stałem się socjalista, w: E. Goldzamt, William Morris a geneza społeczna architektury nowoczesnej, Warszawa 1967, s. 322-326.

Morris W., Nadzieje i troski sztuki. Cztery odczyty, Warszawa 1902.

Morris W., Sztuka a piękność ziemi, w: W. Morris, R. de la Sizeranne, J. Ree, Podstawy kultury estetycznej, Lwów-Warszawa 1906, s. 3-36.

Mortkowiczowa J., O wychowaniu estetycznem, Warszawa 1903.

Pevsner N., Historia architektury europejskiej, Warszawa 1976.

Szulakiewicz W., Biografistyka i jej miejsce w historiografii edukacyjnej po II wojnie światowej, „Biuletyn Historii Wychowania”, 19-20 (2004) s. 5-14, DOI: 10.14746/ bhw.2004.19.20.1.

Winiarski L., William Morris, Warszawa 1900.

Żejmo M., Istota przemian industrialnych w XIX wieku, „Studia Gdańskie. Wizje i rzeczywistość", 12 (2015) S. 169-178. 
